\title{
Relation Between Somatometric and Genitometric Indicators as Reproductive Functions Predictors of Young Men in the Republic of Sakha (Yakutia)
}

\author{
Darima Galmaeva ${ }^{1}$, Lena Arzhakova ${ }^{1}$, Svetlana Vinokurova $^{1, *}$ and Alina Lytkina ${ }^{1}$ \\ ${ }^{1}$ M.K. Ammosov North-Eastern Federal University \\ *Corresponding author. Email: sp.vinokurova@s-vfu.ru
}

\begin{abstract}
This research aims to establish the reference values of genitometric parameters in young men of the pubertant period living in the Republic of Sakha (Yakutia) and the peculiarities of their relation with somatometric and physiometric indicators. 74 young men of Yakut nationality were examined by standard research methods: anthropometry, dynamometry, spirometry, assessment of body composition by bioimpedansiometry and ultrasound of testicular research. Anthropometric parameters have the highest variability, physiometric parameters are the most stable. In two groups of young men with normal and elevated BMI values, differences in component body composition were shown. The most stable were the indicators of body fluids, mineral mass, the most variable is fat mass. Among the genitometric indicators, the most variable were the length of the testicles, the most stable and independently varying are the shyrotic size of the testicles. All orchidometric indicators of the study groups had statistically significant bilateral differences with their right-hand predominance. The results of the research can be applied to facilitate standardization of the assessment of growth, adolescent development of clinical pediatrics and in the field of public health. Obtained data of genitometric indices can be used as reference values in andrological practice for assessment of development and compliance with age norms in diagnosis of disorders.
\end{abstract}

Keywords: genitometric parameters, somatometric indicators, genitometric indicators, reproductive functions, Republic of Sakha (Yakutia)

\section{INTRODUCTION}

It is a well-known fact that modern human conditions lead to a steady deterioration in male fertility rates, a close relation between a decrease in the hormonal function of the testicle with an increased frequency of meta-bolic syndrome, a change in metabolism and the development of cardiovascular and other diseases. Many authors emphasize the urgent need for constant monitoring of the physiological development of the reproductive functions of the male body, revision and development of new regulatory criteria.

It should be noted that some domestic and foreign researchers analyzed the relation of genitometric indicators with data from the general anthropomet and somatotype as conjugated parameters of physical status and re-productive functions (Gayvoronsky I.V., Mazurenko R.G., Lebedev E.Yu., Shalaby M.E., Tikhonov D.A.).

Genitometric indicators are significant criteria for assessing general, reproductive health, gender identity, determining the quality of life in general (Kamalov A.A., Colombo F., Casarico A., Lynn R., Park S., Seo J.T. et al.).

When analyzing scientific resources, we did not find data containing information on genitometric studies of populations living in the Republic of Sakha (Yakutia). Due to the technical and ethical characteristics of such studies, there are comprehensive assessment limits, but, despite this, the problem requires special study. The development of reference values of genitometric parameters of young men, as well as the 
search for laws of the relation of morphometric, physiometric parameters with genitometric parameters in the pubertal period of development of young men of the Republic of Sakha (Yakutia) is relevant.

\section{THE PURPOSE OF THE RESEARCH}

We should establish reference values of genitometric parameters in young men of the pubertant period living in the Republic of Sakha (Yakutia) and the peculiarities of their relation with somatometric and physiometric indicators as conjugated with pre-announcers of reproductive functions.

The objectives are:

1. to determine the variability of somatometric, physiometric parameters, body composition.

2. to set variability of genitometric parameters.

3. to determine the nature and patterns of the relation of somatometric parameters with genitometric parameters.

The scientific and practical significance of the results of the study is determined by establishing the reference values of the main genitometric parameters of young men of pubertant age, which can be an assessment of their reproductive health, somatic pathology and its concomitant disorder, associated with individual anthropometric indicators and changes in body composition. The results of the research can become an informational basis for the advisory and diagnostic practice of doctors of any specialty.

Table 1. Statistical characteristics of anthropometric and physiometric parameters, $\mathrm{p} \leq 0.05$

\begin{tabular}{|l|l|l|l|l|}
\hline & Parameters & $\mathrm{M} \pm \mathrm{m}$ & $\begin{array}{l}\text { minimu } \\
\mathrm{m} \text { values }\end{array}$ & $\begin{array}{l}\text { maximum } \\
\text { values }\end{array}$ \\
\hline 1 & Weight, $\mathrm{kg}$ & $70 \pm 4.39$ & 65.61 & 74.39 \\
\hline 2 & Height, $\mathrm{m}$ & $172.36 \pm 4.17$ & 168.19 & 176.53 \\
\hline 3 & $\begin{array}{l}\text { Waist } \\
\text { circumference, } \\
\text { cm }\end{array}$ & $77.41 \pm 1.89$ & 75.52 & 79.30 \\
\hline 4 & $\begin{array}{l}\text { Hip } \\
\text { circumference }\end{array}$ & $92.71 \pm 2.33$ & 90.37 & 95.04 \\
\hline 5 & Waist/hip ratio & $0.85 \pm 0.04$ & 0.81 & 0.88 \\
\hline 6 & BMl & $22.09 \pm 0.82$ & 18.35 & 25.82 \\
\hline 7 & $\begin{array}{l}\text { Right brush } \\
\text { force, kg }\end{array}$ & $40.28 \pm 1.65$ & 32.76 & 47.81 \\
\hline 8 & $\begin{array}{l}\text { Left hand force, } \\
\text { kg }\end{array}$ & $37.26 \pm 1.52$ & 30.31 & 44.20 \\
\hline 9 & $\begin{array}{l}\text { Starting thrust, } \\
\text { kg }\end{array}$ & $126.97 \pm 8.50$ & 91.21 & 162.74 \\
\hline
\end{tabular}

\begin{tabular}{|c|l|l|l|l|}
\hline 10 & $\begin{array}{l}\text { Lung Capacity } \\
\text { (LL), L }\end{array}$ & $4491.03 \pm 176.17$ & 3697.19 & 5284.86 \\
\hline
\end{tabular}

\section{METHODS AND MATERIALS}

The work was done on the basis of the medical institute of the North-Eastern Federal University named after M.K. Ammosov.

The survey included indigenous boys aged 18-20 years old, permanently living in the Republic of Sakha (Yakutia), who were students of the 1st year of NEFU in all specialties, a total of 74 people, 29 boys of which agreed to ultrasound examination of the genitals. Conventional techniques were used in the study. Anthropometric measurements included measurements of total body size and weight: body length $(\mathrm{cm})$, body mass $(\mathrm{kg})$, chest circumference $(\mathrm{CC}, \mathrm{cm})$, waist circumference $(\mathrm{WC}, \mathrm{cm})$, and thigh $(\mathrm{CT}, \mathrm{cm})$ The functional measures study included measurement of lung vital capacity (VC) and strength of individual muscles. The life capacity of the lungs (VC) was measured by spirometry using the SpiroC- 100 apparatus. Measurement of muscle strength was carried out by dynamometry using a handgrip test on both hands and machine dynamometry. The component composition of the body was evaluated by bioimpedancometry using the Medass-ABC 01 device.

Ultrasonic examination of the scrotum was carried out in a lying position on the back on a portable highend ultrasonic sonograph of the Mindray M7 type using a $7.5 \mathrm{MHz}$ linear sensor. According to the generally accepted standard, ultrasonic scanning of testicles was done in three projections: width and thickness were determined in a transverse projection, and length in a longitudinal projection, appendages in two projections: length and width. The volume of testicles in $\mathrm{ml}$ was calculated by the Brown formula (1981): $\mathrm{V}=0.52 *$ $\mathrm{ABC}$ where $\mathrm{A}$ length, $\mathrm{B}$ width and respectively $\mathrm{C}$ testicle thickness in $\mathrm{mm}, 0.52$ - refined coefficient pi/6.

Statistical processing of the results was carried out with the information and analytical system of the SOMAX database. For normal distribution data, the mean (M) and confidence interval step (m) were calculated. The validity of differences in sample averages was assessed by the Student's t-test; the MannWhitney method for features with non-parametric -Utest distribution. The results were considered statistically significant at $\mathrm{p}<0.05$. This approach provided a comprehensive and reliable study of the material received.

Measurements were carried out with the principles of volunteerism, individual rights and freedom guaranteed by Article 21 and 22 of the Constitution of the Russian Federation. The work performed does not infringe rights and does not endanger the well-being of 
research subjects in accordance with the requirements of biomedical ethics approved by the Helsinki Declaration of the World Medical Association (2000). All study subjects had individual informed consent to participate in the study.

\section{RESULTS AND DISCUSSION}

\section{Variability of anthropometric and physiometric indicators of young men.}

Table 1 shows the main indicators of the physical development of young men aged 18-20 years old. The average value of the body mast index (BMI) of young men was $22.09 \pm 0.82$. Normal body weight was determined in $78.2 \%$ of boys, excess weight $-21.8 \%$. Obesity and underweight were not detected in the examined group of boys.

According to FNKTS FMBA of Russia, 2018 set one-dimensional centile scales for assessing the physical development of young men from 17 to 20 years old, according to which the growth and BMI results correspond to average indicators, and dynamometry indicators are lower than Russian values (normal dynamometry of the right hand is $45.9-51 \mathrm{~kg}$.) [1]. The LVC values in our study corresponded to the proper LVC (dVC), calculated by V.A. Pestryaev formula, 2017 [2] in $74 \%$ of young men, in $26 \%$ were below dVC.

Analysis of scientific literature showed that low skeletal muscle mass directly correlates with decreased lung function in asymptomatic adults without clinically obvious lung diseases [3]. A negative correlation between obesity and lung volumes in children and adolescents was also demonstrated, excessive weight reduces functional residual capacity, reserve exhalation volume and residual volume [4]. Other studies have traced the correlation between lung volumes and dynamometry scores. A significantly low, moderately positive association of lung volume in young men and BMI was reported [5]. In other studies, no direct correlation was detected [6].

\section{Dependence of bioimpedanciometry indicators on BMI}

We compared data of bioimpedance values depending on BMI in Table 2. since the study group was dominated by boys with normal BMI (18.5-24.9 kg/m²) and increased BMI (> $25 \mathrm{~kg} / \mathrm{m}^{2}$ ) according to the international classification of obesity according to BMI, WHO, 1997 [7].

The results presented in Table 2 indicate that in students with BMI > $25 \mathrm{~kg} / \mathrm{m}^{2}$, most bioimpedancometric parameters had statistically significantly large values compared to similar rates of students with normal BMI $\left(18.5-24.9 \mathrm{~kg} / \mathrm{m}^{2}\right)$ on the background of lower specific underlying exchange values. It should be noted that the value of the phase angle of bioimpedance and the relative amount of active cell mass is the same in both groups of students, regardless of BMI, this indicates the intensity of metabolism and a good level of physical performance.

Table 2. Indicators of bioimedance analysis of young men's body composition depending on BMI, $\mathrm{p} \leq 0.05$

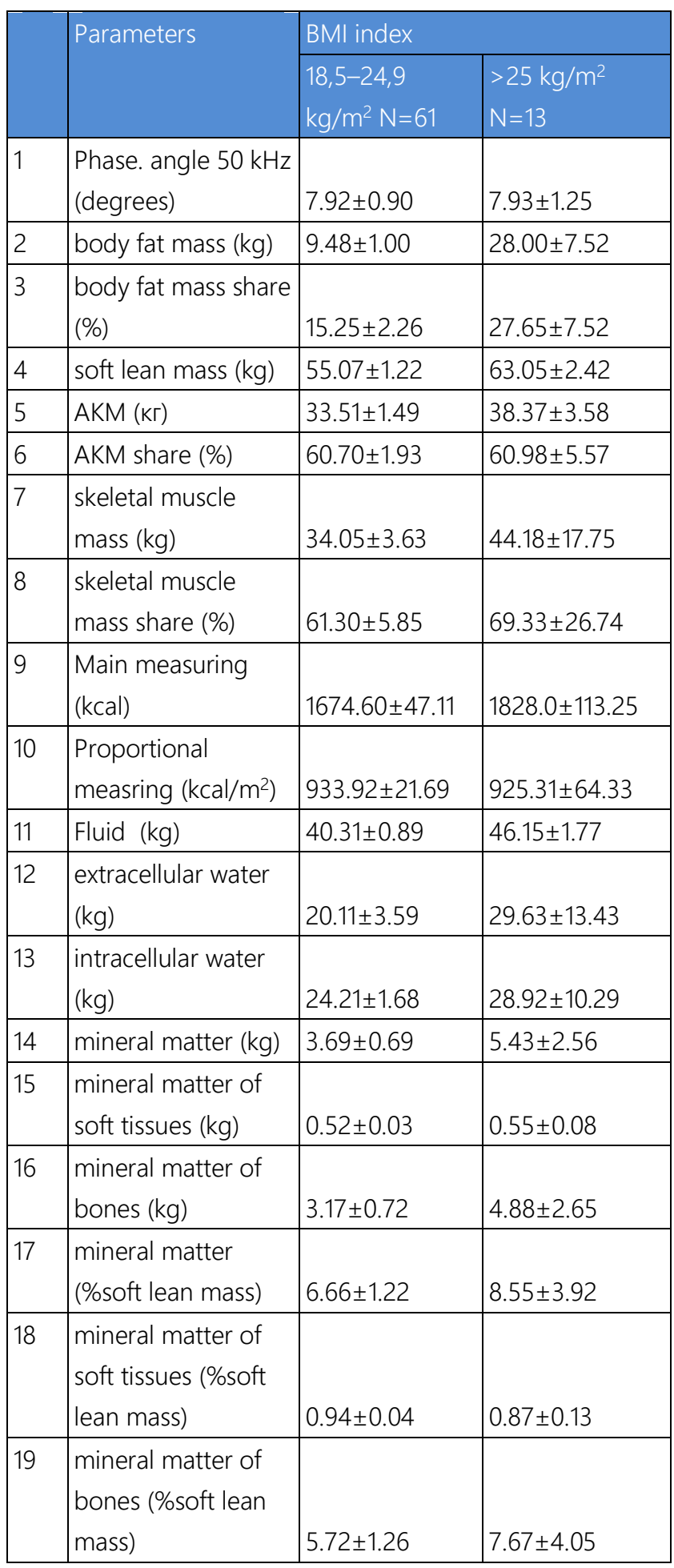


Anthropometric indicators of the studied group of young men in comparison with the indicators of the same age group living in different regions differ in the following parameters: researches by Omsk State Medical Academy showed that young men in $37 \%$ were dominated by excess body weight, in $9 \%$ - lack of body weight [8]; students of Krasnoyarsk Medical University found that $14.48 \%$ of first-year students had deviations in mass indicators, BMI $<18.5 \mathrm{~kg} / \mathrm{m}^{2}$ was detected in $7.42 \%$, BMI > $25 \mathrm{~kg} / \mathrm{m}^{2}$, indicating increased body weight or obesity in $7.06 \%$ students [9]; $40 \%$ of students - young men living in the Republic of Mordovia had excess body weight, $19 \%$ - insufficient body weight [10].

In addition, the result of comparison of anthropometry and bioimpedancometry data established that indicators of growth, lung capacity, weight, waist circumference (WC), thigh circumference $(\mathrm{CH})$, ration of waist and thigh circumference, basic metabolism (BM) normalized by body fat mass (FM), FM classification by percentage, soft lean mass (SLM), skeletal muscle mass (SMM) in boys with normal and overweight had statistically significant differences.

The analysis of foreign scientific literature shows that there are state programs for a comprehensive study of the development of children of different ages in many countries. Papers published in Norway, Belgium, Denmark and other Western European countries reflect the increasing prevalence of overweight and obesity [11-13].

Studies of Chinese adolescents showed differences for each physical development indicator for almost all ages between China and WHO. The growth of Chinese boys is markedly lower than that of WHO over the age of 15 , and BMI at this age is usually slightly higher [14]. A study of adolescent development in the State of Bahrain has found that over the past decade there has been a tendency to increase BMI, skin fold thickness and body fat percentage [15].

\section{Variability of genitometric indicators of the studied group of young men.}

The next task of the study was to show the nature and patterns of the relationships between somatometric and genitometric indicators of young men.

In general, available studies show that penile sizes and other anthropometric indicators, even within the same age groups, are subject to significant indie-visual, group, racial and ethnic variability [16]. There are contradictory data on the correlation of phallometric data and the principles of their typology in terms of the constitutional approach. Single studies of dimensional characteristics of the external genitalia were compared with the corresponding data on the hormonal background and orchidometry.
Undoubtedly, the best and most objective clinical marker of puberty in men is the assessment of testicular volume [17]. To do this, we conducted an ultrasound study of testicles and appendages in a limited number of young men, the results are presented in Table 3.

Table 3. Statistical characterization of geniometric parameters $(n=29), p \leq 0.05$

\begin{tabular}{|l|l|l|l|l|}
\hline & Parameter & $M \pm m$ & $\begin{array}{l}\text { Minimum } \\
\text { values }\end{array}$ & $\begin{array}{l}\text { Maximum } \\
\text { values }\end{array}$ \\
\hline 1 & $\begin{array}{l}\text { Right testicle volume, } \\
\mathrm{cm}^{3}\end{array}$ & $15.46 \pm 0.51$ & 14.14 & 16.79 \\
\hline 2 & $\begin{array}{l}\text { right testicle length, } \\
\text { cm }\end{array}$ & $4.29 \pm 0.14$ & 3.93 & 4.64 \\
\hline 3 & $\begin{array}{l}\text { thickness of the right } \\
\text { testicle, cm }\end{array}$ & $2.22 \pm 0.09$ & 1.98 & 2.46 \\
\hline 4 & $\begin{array}{l}\text { width of the right } \\
\text { testicle, cm }\end{array}$ & $3.12 \pm 0.12$ & 2.96 & 3.28 \\
\hline 5 & $\begin{array}{l}\text { volume of left testicle, } \\
\text { cm }{ }^{3}\end{array}$ & $15.36 \pm 0.57$ & 13.90 & 16.82 \\
\hline 6 & $\begin{array}{l}\text { length of left testicle, } \\
\text { cm }\end{array}$ & $4.28 \pm 0.07$ & 4.09 & 4.46 \\
\hline 7 & $\begin{array}{l}\text { thickness of left } \\
\text { testicle, cm }\end{array}$ & $2.18 \pm 0.05$ & 2.05 & 2.31 \\
\hline 8 & $\begin{array}{l}\text { width of left testicle, } \\
\text { cm }\end{array}$ & $3.16 \pm 0.06$ & 3.01 & 3.31 \\
\hline 9 & $\begin{array}{l}\text { diameter of the head } \\
\text { of the right } \\
\text { appendage, cm } \\
\text { ap }\end{array}$ & $1.09 \pm 0.05$ & 0.97 & 1.22 \\
\hline 11 & $\begin{array}{l}\text { dickness of the head } \\
\text { appendage, cm }\end{array}$ & $0.90 \pm 0.10$ & 0.80 & 0.99 \\
\hline appendage head, cm & $0.91 \pm 0.03$ & 0.82 & 1.00 \\
\hline $\begin{array}{l}\text { thickness of left } \\
\text { appendage head, cm }\end{array}$ & 0.95 & 1.24 \\
\hline
\end{tabular}

Thus, according to the obtained data, young men already have statistically highly significant bilateral differences in testicular size, the parameters of the right testicle significantly exceed the parameters of the left testicle at the age of growth stabilization and transition to maturity. The total volume of the testicles was 30.82 $\pm 0.51 \mathrm{ml}$.

So, in the general population of young men of Krasnoyarsk at the age of 17-21, the volume of the right testicle was $16.9 \mathrm{~cm}^{3}$, the left $15.9 \mathrm{~cm}^{3}$, the total volume of the testicles $32.8 \mathrm{~cm}^{3}$. In young men of different types of physique, as well as in the general group, the 
volume of the right testicle is greater than the volume of the left testicle [18].

In the studies of Tikhonov D.A. the volume of the left testicle was $14.3 \pm 0.61 \mathrm{ml}$, the right $-16.5 \pm 1.10$ $\mathrm{ml}$. in young men of Ulyanovsk of this age group. The largest fluctuations in values were inherent in the volume of the right testicle - from $3.35 \mathrm{ml}$ to $51.9 \mathrm{ml}$. The total volume of the testicles was $30.7 \pm 1.63 \mathrm{ml}$ with $95 \%$ confidence interval from 27.5 to $34 \mathrm{ml}$. [16].

In Turkish boys aged $20.3 \pm 0.9$ years old, the average testicular volume was $22.0 \pm 2.8 \mathrm{~cm}$. A weak positive correlation between penile length and average testicular volume was found, weak positive correlations between penile length (both lethargic and stretched) and height, weight and body mass index, respectively. These results demonstrate that somatometric parameters correlate with penile length [19].

In studies conducted in Italian young men, BMI was positively associated with difference in arm span and negatively with penile length; $23.2 \%$ of test subjects had a low average testicular volume $(<12 \mathrm{ml})$ [20].

A factor analysis was carried out to clarify the nature of the relation between the absolute values of the measured features and body composition indicators. Its results are shown in Table 4.

Table 4. Values of statistically significant correlation coefficients of Pearson genitometric and some bioimpedance parameters $(\mathrm{r}, \mathrm{p}<0.05)$

\begin{tabular}{|l|l|l|l|l|l|}
\hline Parameters & $\begin{array}{l}\text { Phase } \\
\text { angle }\end{array}$ & $\begin{array}{l}\text { Body } \\
\text { fat } \\
\text { mass }\end{array}$ & $\begin{array}{l}\text { skeletal } \\
\text { muscle } \\
\text { mass }\end{array}$ & AKM & $\begin{array}{l}\text { Mineral } \\
\text { mass }\end{array}$ \\
\hline $\begin{array}{l}\text { average } \\
\text { testicular } \\
\text { volume }\end{array}$ & 0.57 & $\begin{array}{l}-0.20 \\
\text { Н.Д. }\end{array}$ & 0.31 & 0.47 & $\begin{array}{l}0.21 \\
\text { Н.Д. }\end{array}$ \\
\hline
\end{tabular}

Thus, the general conclusion that follows from the data presented in Table 4 is genitometric and bioimpedance indicators are interconnected. Weak correlation of average testicular volume and active cell mass, musculoskeletal mass and moderate correlation with phase angle value was found. The results obtained are of interest and require further study.

\section{CONCLUSIONS}

1. Anthropometric parameters, such as weight (70.0 $\pm 4.39 \mathrm{~kg}$ ), have the highest variability, the most stable are physiometric (right hand force $40.28 \pm 1.65 \mathrm{~kg}$ ). In two groups of young men with normal and increased BMI values, the fat body weight of the studied men was $9.48 \pm 1.00$ and $28.00 \pm 7.52 \mathrm{~kg}$, soft lean mass (fatfree) was $55.07 \pm 1.22$ and $63.05 \pm 2.42$, active cellular $-33.51 \pm 1.49$ and $38.37 \pm 3.58$, musculoskeletal -
$34.05 \pm 3.63$ and $44.18 \pm 17.75 \mathrm{~kg}$, respectively. The phase angle in both groups was $7.92 \pm 0.90$ and $7.93 \pm$ 1.25. The most stable are the indicators of water content in the body, mineral mass, the most variable is fat mass.

2. The most variable are the length of the testicles (the length of the right was $4.29 \pm 0.14$ ), the most stable and independently varying are the shyrotic dimensions of the testicles (the thickness of the left testicle was $2.18 \pm 0.05 \mathrm{~cm})$. All orchidometric indices of the examined groups have statistically significant bilateral differences with their right-hand predominance.

3. Statistically significant correlation $(r=0.57$, $\mathrm{p}<0.05$ ) is inherent for the average volume of testicles with a phase angle, moderate - with indices of active cell mass $(r=0.47, p<0.05)$ and musculoskeletal mass. $(\mathrm{r}=0,31, \mathrm{p}<0,05)$.

4. The results of the study can be applied to facilitate standardization of the assessment of growth, adolescent development of clinical pediatrics and in the field of public health. Obtained data of genitometric indices can be used as reference values in andrological practice for assessment of development and compliance with age norms in diagnosis of disorders.

\section{REFERENCES}

[1] V.D. Vybornov, J.V. Grishina, A.V. Zholinsky et al., Methodical recommendations for determining the deficiency of biologically active substances (BAV) in children involved in sports, FMBA of Russia, Moscow, 2018.

[2] V.A. Pestryaev, How to determine the proper life capacity of a patient's lungs, Patent no. 2677012 C1 Russian Federation, IPC A61B 5/00, no. 2017142666 (2017).

[3] C.H. Park, Y. Yi, J.G. Do et al., Relationship between skeletal muscle mass and lung function in Korean adults without clinically apparent lung disease, Med. (Baltimore) 97(37) (2018) 12281.

[4] L.J. Richard, M.-U. N. Magdalene, The Effects of Body Mass Index on Lung Volumes, Chest. 130(3) ( 2006) 827-833.

[5] T.H. Musa, W. Li, W. Yan et al., Association between the effects of body mass index on lung volumes among students in Jiangsu Province, Polish. Ann. of Med. 25(2) (2018) 190-195.

[6] P. Liu, Z. Ye, H. Lu et al., Association between body mass index (BMI) and vital capacity of college students of Zhuang nationality in China: a cross-section study, Oncotarget. 8 (2017) 80923 80933. 
[7] World Health Organization, Obesity: preventing and managing the global epidemic, WHO, Geneva, 1997.

[8] E.G. Blinova, I.S. Akimova, M.G. Chesnokova, L.V. Demakova, The results of the analysis of anthropometric and bioimpedanesometric studies in students of Omsk, Modern probl. of sci. and ed. 3 (2014) 543-551.

[9] M.V. Peshkov, E.P. Sharaikina, Gender characteristics of bioimpedancometry indicators depending on student body mass index, Siber. Med. Rev. 6 (2014) 52-57.

[10] D.S. Blinov, O.A. Smirnova, N.N. Chernova et al., The results of the analysis of the students' body composition by bioimpedance method, Mord. Univ. Bull. 2(26) (2016) 192-202.

[11] M. Roelants, R. Hauspie, K. Hoppenbrouwers, References for growth and pubertal development from birth to 21 years in Flanders, Belgium, Ann. Hum. Biol. 36(6) (2009) 580-694.

[12] P.B. Juliusson, M. Roelants, E. Nordal et al., Growth references for 0-19year-old Norwegian children for length/height, weight, body mass index and head circumference, Ann. Hum. Biol. 40(3) (2013) 220-227.

[13] N. Cameron, British growth charts for height and weight with recommendations concerning their use in auxological assessment, Ann. Hum. Biol. 29(1) (2002) 1-10.

[14] X.N. Zong, H. Li, Construction of a new growth references for China based on urban Chinese children: comparison with the WHO growth standards, PLoS One 8(3) (2013) 59569.

[15] A.M. Al-Sendi, P. Shetty, A.O. Musaiger, Anthropometric and body composition indicators of Bahraini adolescents, Ann. Hum. Biol. 30(4) (2003) 367-379.

[16] D.A. Tikhonov, Features of relations between somatometric and genitometric indicators of young men and young men, Ph.D. Thesis, Simferopol, 2017.

[17] F.M. Biro, A.W. Lucky, G.A. Huster, J.A. Morrison, Pubertal staging in boys, J. Pediatr. 127(1) (1995) 70262-702652.

[18] V.Yu. Burgart, N.N. Medvedev, Constitutional features of testicular volume and basic ejaculate indicators of young men of Krasnoyarsk, Nat. Sci. and Human. Coll. of sci. works 3(1) (2006).

[19] Y1. Aslan, A. Atan, A.O. Aydin et al., Penile length and somatometric parameters: a study in healthy young Turkish men, Asian. J. Androl. 13(2) (2013) 339-341.

[20] C. Foresta, A. Garolla, A.C. Frigo et al., Anthropometric, penile and testis measures in postpubertal Italian males, J. Endocrinol. Invest. 36(5) (2013) 287-292. 